\title{
Toxic Effect of Cadmium Assay in Contaminated Soil Earthworm Cell Using Modified Sensor
}

\author{
Suw Young Ly, Lee Kyung, Chae Hwa Kim, Roma Seo, Soo Youn Lee, Lina Kim, \\ Su min Chae, Sung Wook Choi and Ji Yoon Kim \\ Biosensor Research Institute, Seoul National University of Science \& Technology, Seoul, Korea
}

(Received May 21, 2015; Revised June 25, 2015; Accepted June 26, 2015)

\begin{abstract}
A voltammetric toxic metal of cadmium detection was studied using a fluorine doped graphite pencil electrode (FPE) in a seawater electrolyte. In this study, square wave (SW) stripping and chronoamerometry were used for determination of $\mathrm{Cd}$ (II) in seawater. Affordable pencils and an auxiliary electrode were used as reference. All experiments in this study could be performed at reasonable cost by using graphite pencil. The application was performed on the tissue of contaminated soil earthworm. The results show that the method can be applicable for vegetables and in vivo fluid or medicinal diagnosis.
\end{abstract}

Key words: Cadmium, Voltammetry, Tissue, Seawater electrolyte

\section{INTRODUCTION}

Cadmium $(\mathrm{Cd})$ is a toxic metal occurring naturally in the environment and as a pollutant emanating from industrial and agricultural water sources (1). Cadmium ions are easily absorbed by vegetables from water resource and, in animalbased food, are principally distributed in the liver and kidneys (2). Some studies have reported that $\mathrm{Cd}$ is associated with some disease such as Itai-itai (3), Alzheimer's (4), diabetes, chronic kidney diseases (5), and renal cancer (6). Many studies have been conducted to determine the toxicity of Cd. A lot of spectrometric studies have been investigated such as flame atomic absorption spectrometric determination $(7,8)$, inductively coupled plasma optic emission spectrometry (9), thermal atomic absorption spectrometry $(10,11)$, kinetic methods (12) sequential multi-element flame atomic absorption spectrometry (13), hydride generation atomic absorption spectrometry (14), CPE (The chemical variables affecting cloud point extraction) molecular fluorescence combined methodology (15), beam injection flame furnace atomic absorption spectrometry (16), and

Correspondence to: Suw Young Ly, Biosensor Research Institute, Seoul National University of Science \& Technology, 172, Gongreung 2dong Nowongu, Seoul 139-743, Korea

E-mail: suwyoung@snut.ac.kr

This is an Open-Access article distributed under the terms of the Creative Commons Attribution Non-Commercial License (http:// creativecommons.org/licenses/by-nc/3.0) which permits unrestricted non-commercial use, distribution, and reproduction in any medium, provided the original work is properly cited. other absorption spectrometries (17-20). These devices are expensive and time-consuming, compared to voltammetric methods which are affordable and fast. Here, voltammetric methods have been studied actively such as carbon paste (21) modified (22) glassy carbon (23) platinum (24), mercury (25) and nanotube (26) sensors. Moreover, in this study, reasonable graphite pencil electrodes were used instead of expensive electrodes, and flourine was doped on a working electrode. All examinations were performed in seawater electrolyte solution. Analytical application was also performed on the tissue of contaminated soil earthworm. The results show that they can be used for medicinal diagnostic assays.

\section{MATERIALS AND METHODS}

Systems, reagents, electrode preparation, and experimental procedure. Experimental systems were carried out using a bioelectronics-2 structure, which was constructed by the authors' institution. Their version was fabricated to a computerized handheld voltammetric system with a $2.4 \mathrm{~V}$ potential windows, a $2 \mathrm{~mA}$ current range, a 10 pico A measuring current, and a 5"4"1" compact size. The size of the instrument was similar to that of a typical cellular phone. The FPE was prepared using coated fluorine and nafion on the graphite pencil, and graphite pencil electrode (PE) was prepared. Two pencils served as the reference and auxiliary electrodes. The supporting electrolyte was prepared using deep seawater. All the other reagents were of analytical grade. Electrolyte voltammetry was carried out in 
an open circuit. In a $5 \mathrm{~mL}$ conc HF solution, fluorine was doped using a 10 -cycle scan with a $1.0 \mathrm{~V}$ initial potential, a $1.0 \mathrm{~V}$ switching potential, and a $0.5 \mathrm{Vs}^{-1}$ scan rate. The SW stripping voltammograms used the following parameters: $0.06 \mathrm{~V}$ amplitude, $25 \mathrm{~Hz}, 170 \mathrm{sec}$ deposition time, and $-1.3 \mathrm{~V}$ initial potential. All experiments were performed at room temperature and without oxygen removal.

\section{RESULTS AND DISCUSSION}

First, high concentration of Cd was examined with SW using PE in seawater electrolyte. In this study, inexpensive and renewable pencils were used as working, reference, and auxiliary electrodes. Fig. 1A shows that SW examination ranges from 0 to $100 \mathrm{mg} / \mathrm{L}$ concentration using PE. At $10 \mathrm{mg} / \mathrm{L}$, the peak current of $0.1016 \times 10^{-3}$ was obtained. It increased quickly to $0.2810 \times 10^{-3}$ at $20 \mathrm{mg} / \mathrm{L}$, but decreased at $30 \mathrm{mg} / \mathrm{L}$. After a decline, it started to increase again and oscillated. Fig. 1B illustrates the SW FPE results of micro ranges. The concentration of ranges from 0 to $10 \mathrm{mg} / \mathrm{L}$ was spiked. Two peak current were obtained at $3.13 \times 10^{-6} \mathrm{~A}$ $(0.1 \mathrm{~V})$ and $5.073 \times 10^{-6} \mathrm{~A}(-0.5 \mathrm{~V})$ increased quickly as more concentrations of $\mathrm{Cd}$ spike. The curves also became sharper according to the increase of the peak currents. These linear equations was of $\mathrm{y}=18.527 \mathrm{x}-32.321, \mathrm{R}^{2}=$ 0.9898 , and $y=10.326 x-9.871, R^{2}=0.9809$, both can be usable for cathodic scan. Fig. $1 \mathrm{C}$ also shows the $\mathrm{CV}$ effects in microgram ranges. The anodic small peak of $1.057 \times$ $10^{-4} \mathrm{~A}$ was obtained at $1 \mathrm{mg} / \mathrm{L}$. After that, it increased continuously and reached $10.540 \times 10^{-4} \mathrm{~A}$. Working curve was of $\mathrm{y}=1.1487 \mathrm{x}+0.3058, \mathrm{R}^{2}=0.9487$. Thus the seawater electrolyte, good results were examined using FPE.

SW Optimizations of FPE. Fig. 2A shows the results of chronoamerometry. Every 25 seconds, each $25 \mathrm{mg} / \mathrm{L} \mathrm{Cd}$ was spiked by 9 point at $-0.6 \mathrm{~V}$ oxidation potential. The step current was linear from 25 to $225 \mathrm{mg} / \mathrm{L}$ variations. The peak current was obtained every time $\mathrm{Cd}$ was spiked. It obtained $5.092 \times 10^{-5} \mathrm{~A}$ at 25 seconds and increased continuously to $34.832 \times 10^{-5} \mathrm{~A}$. The equation of these curves was sensitive for $\mathrm{y}=0.144 \mathrm{x}+4.274$ and the precision $\mathrm{R}^{2}=$ 0.978 , can be applicable for mili ranges. Under these conditions, Fig. 2B shows the result of statistics effects using $10 \mathrm{mg} / \mathrm{L}$ constant. Based on optimum conditions, the precision was examined with $13^{\text {th }}$ determination of the standard spike. The result of standard deviation was 0.13369 . This shows FPE is stable for the detection of $\mathrm{Cd}$. Here can be used to analytical working ranges and application.

Analytical working range and statistics. Under optimum conditions, analytical working ranges were examined using $\mathrm{CV}$ and $\mathrm{SW}$ in seawater electrolyte. Fig. 3A shows the $\mathrm{CV}$ results of $10 \sim 80 \mu \mathrm{g} / \mathrm{L}$ variations with 8 points. In the blank solution, no signal was obtained. The peak cur-
(A)

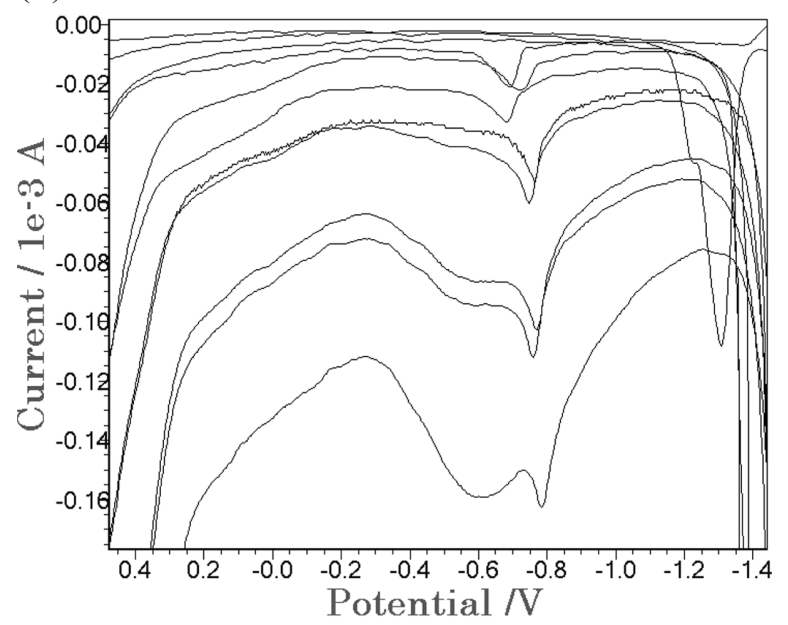

(B)

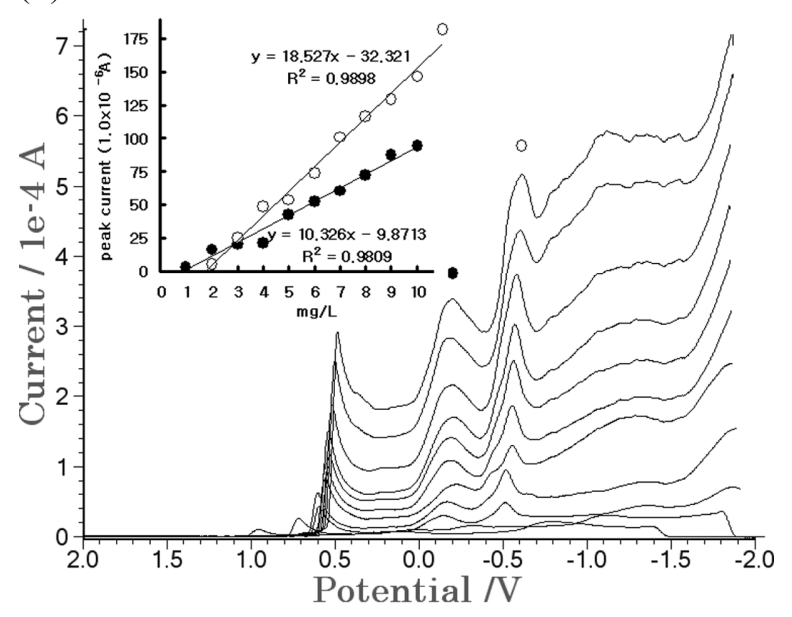

(C)

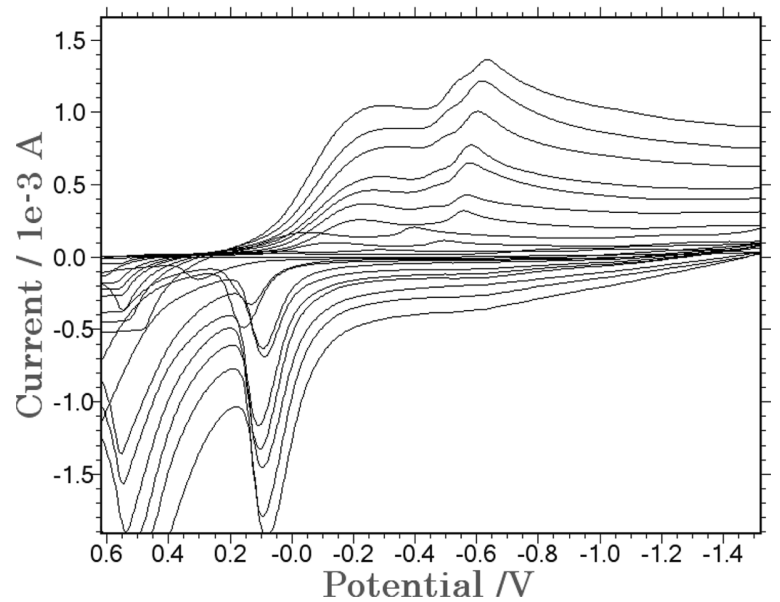

Fig. 1. (A) Stripping voltammetry using $P E$ for $\mathrm{Cd}$ variations. The first curve is blank and $0 \sim 100 \mathrm{mg} / \mathrm{L} \mathrm{Cd}$ spike with 10 points in the seawater electrolyte. (B) SW effect in lower concentrations of 1, 2, 3, 4, 5, 6, 7, 8, 9, and $10 \mathrm{mg} / \mathrm{L}$ spike fluorine-doped FPE electrode. (C) Cyclic voltammetry in the range of $0,1,2,3$, $4,5,6,7,8,9$, and $10 \mathrm{mg} / \mathrm{L} \mathrm{FPE}$. The first curve represents the blank solution and no signal was obtained. 
(A)

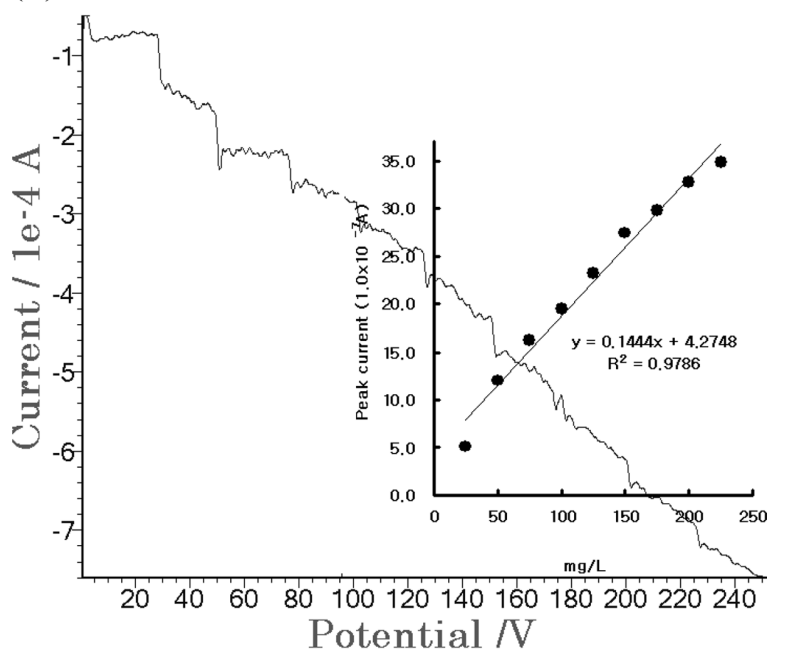

(B)

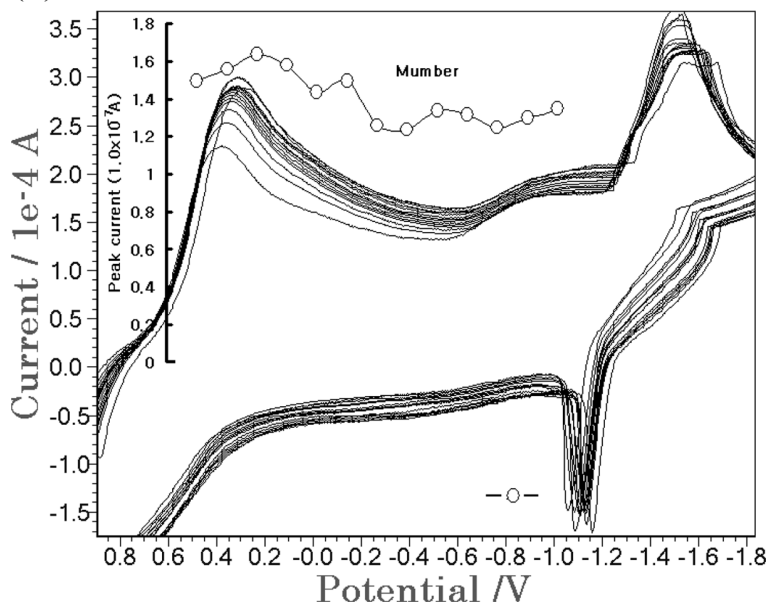

Fig. 2. (A) The results of chronoamerometric concentration effects for $25-225 \mathrm{mg} / \mathrm{L} \mathrm{Cd}$ add with 25 seconds, $-0.6 \mathrm{~V}$ oxidation potential. (B) The statistics using $10 \mathrm{mg} / \mathrm{L} \mathrm{Cd} \mathrm{FPE} \mathrm{electrode}$ with CV with optimum conditions.

rent increased from $6.143 \times 10^{-6} \mathrm{~A}$ to $51.220 \times 10^{-6} \mathrm{~A}$ oxidation. The curve became sharper and linear. After that, the SW anodic and cathodic scans were examined in micro ranges. Fig. 3B shows the anodic scan from 10 to $80 \mu \mathrm{g} / \mathrm{L}$ with 8 point spike. The curve was narrowed forward to the bottom. Linear equation was $\mathrm{y}=0.8031 \mathrm{x}-15.206$ and $\mathrm{R}^{2}=$ 0.884 , which can be applicable for any field. Moreover, Fig. $3 \mathrm{C}$ shows the $\mathrm{SW}$ examination on cathodic scan from 10 to $80 \mu \mathrm{g} / \mathrm{L}$. The peak current increased continuously from $1.357 \times 10^{-6} \mathrm{~A}$ to $6.961 \times 10^{-6} \mathrm{~A}$. Linear equation of $\mathrm{y}=$ $0.0781 \mathrm{x}+1.0428$ and precision of $\mathrm{R}^{2}=0.9599$ were obtained. After the working ranges, low detection limits were examined and the application was performed.

In vivo applications. The examination of $\mathrm{Cd}$ in the earthworm tissue was examined using the standard addition
(A)

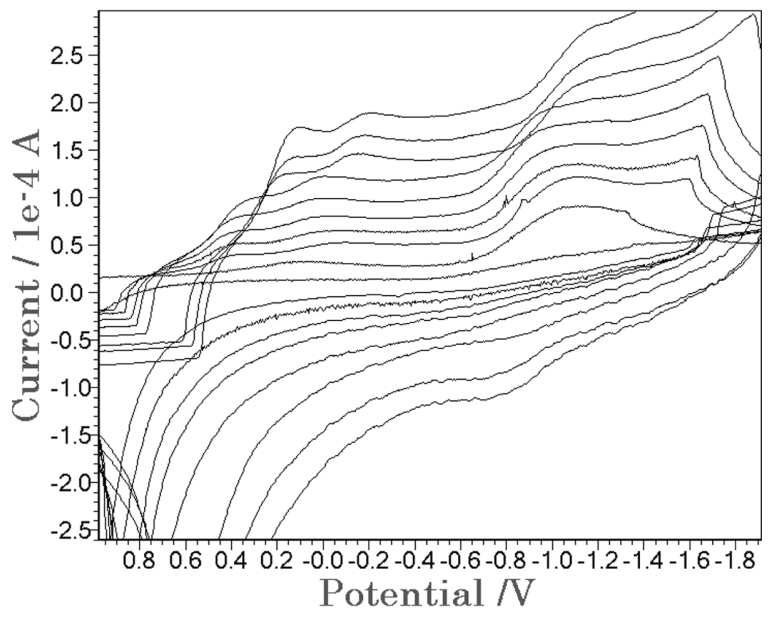

(B)

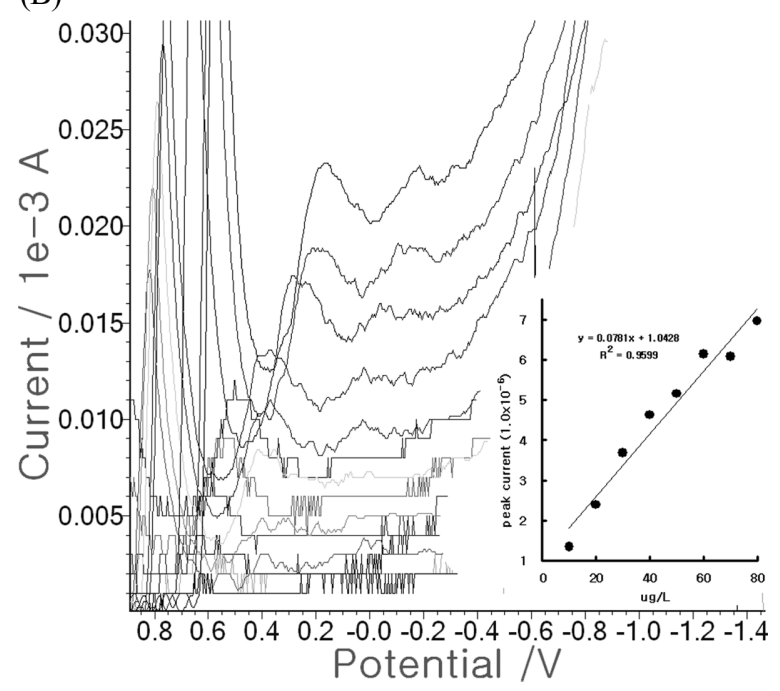

(C)

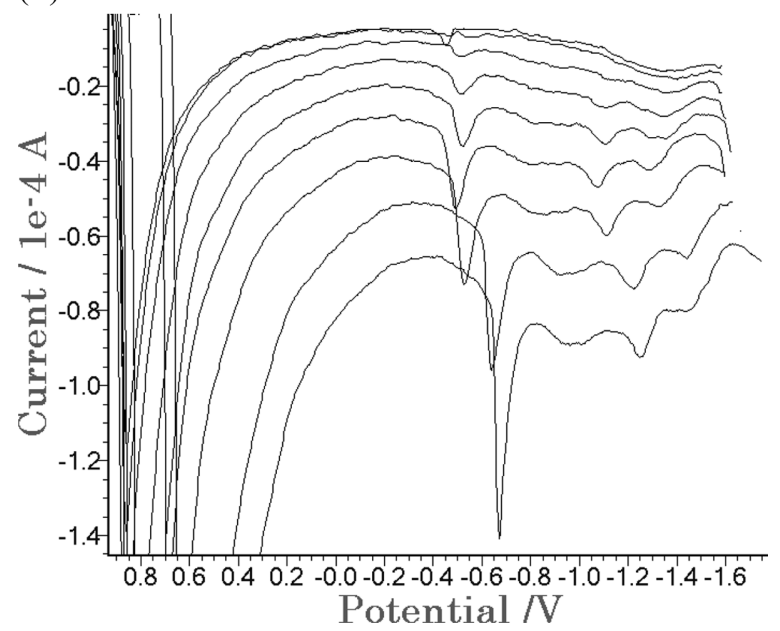

Fig. 3. (A) The CV for analytical working ranges of 10, 20, 30, 40, $50,60,70$, and $80 \mu \mathrm{g} / \mathrm{L} \mathrm{Cd}$ ion spike using FPE electrode. (B) The SW anodic working ranges from 0 to $80 \mu \mathrm{g} / \mathrm{L}$. (C) The cathodic scan of SW ranges of $0,20,30,40,50,60,70$, and $80 \mu \mathrm{g} / \mathrm{L} \mathrm{Cd}$ ion spike in seawater electrolyte under optimum conditions. 


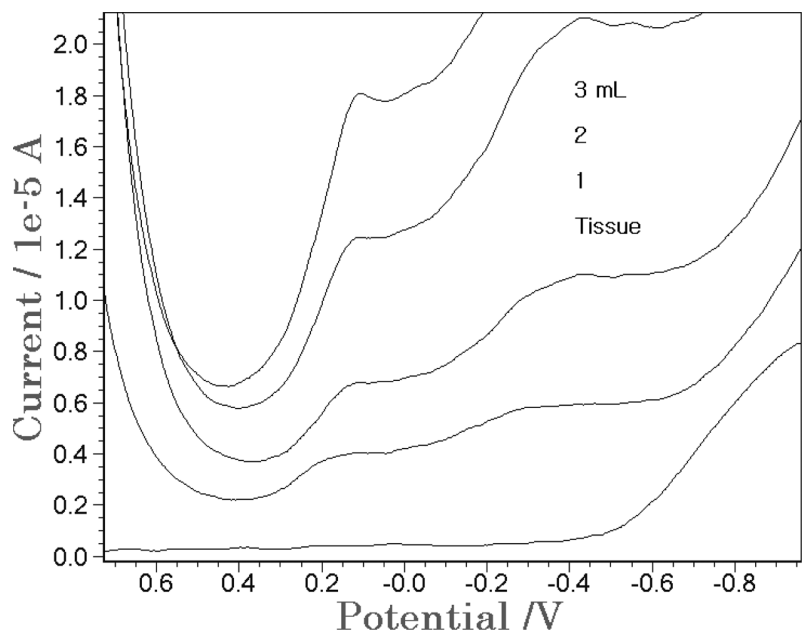

Fig. 4. Determination of $\mathrm{Cd}$ in the contaminated site of earthworm cell using the standard addition method. The bottom curve is the result of the blank solution. The unknown solution that dissolved the earthworm tissue in the nitrate was spiked. Then 1, 2, and 3 standard Cd solution was spiked in order based on optimum condition.

method in seawater electrolyte. Fig. 4 shows the results of the analytical detection in the range of microgram additions. Before experimenting on the application, an unknown cell tissue was prepared. This solution was made by dissolution of earthworm tissue for $0.5 \mathrm{~g} / 10 \mathrm{~mL}$ nitrate with heating in the $100 \mathrm{~mL}$ distilled water. $2 \mathrm{~mL}$ unknown solution was spiked at first, then the 1, 2, $3 \mathrm{~mL} \mathrm{Cd}$ standard was spiked in order. The first curve represents the blank solution. The peak current was obtained at 7.224, 14.620, 32.72, and $42.84 \times 10^{-7} \mathrm{~A}$, respectively. Here, the working equation was $\mathrm{y}=14.386 \mathrm{x}-11.947, \mathrm{R}^{2}=0.9414$, and standard addition methods were obtained for $0.6801 \mathrm{mg} / \mathrm{L}$ containing tissue solutions. The results, which were significant and sharp, are usable for medicinal diagnosis. The developed technique can be applied to in vivo fluid diagnosis of live organs.

Stripping voltammetry was examined for detecting $\mathrm{Cd}$ using FPE in seawater solution. The optimum condition was as follows: $-0.035 \mathrm{~V}$ amplitude, $5 \mathrm{~Hz}$ frequency, and 60 seconds accumulation time for cathodic scan; and $0.04 \mathrm{~V}$ amplitude, $15 \mathrm{~Hz}$ frequency and 90 seconds accumulation time for anodic scan (not shown here). Under these conditions, the detection limit was obtained at $6.0 \mu \mathrm{g} / \mathrm{L}$ by using this developed sensor. The standard addition method was used for application in earthworm cell. The result of the application shows that it can be applied for based food systems or in vivo diagnosis. It can also be applied for medical fields that require $\mathrm{Cd}$ detection.

\section{REFERENCES}

1. Järup, L. and Akesson, A. (2009) Current status of cadmium as an environmental health problem. Toxicol. Appl. Pharmacol., 238, 201-208.

2. Oymak, T., Tokalıoğlu, S., Yılmaz, V., Kartal, S. and Aydın, D. (2009) Determination of lead and cadmium in food samples by the coprecipitation method. Food Chem., 113, 13141317.

3. Inaba, T., Kobayashi, E., Suwazono, Y., Uetani, M., Oishi, M., Nakagawa, H. and Nogawa, K. (2005) Estimation of cumulative cadmium intake causing Itai-itai disease. Toxicol. Lett., 159, 192-201.

4. Panayi, A.E., Spyrou, N.M., Iversen, B.S., White, M.A. and Part, P. (2002) Determination of cadmium and zinc in Alzheimer' brain tissue using inductively coupled plasma mass spectrometry. J. Neurol. Sci., 195, 1-10.

5. Edwards, J.R. and Prozialeck, W.C. (2009) Cadmium, diabetes and chronic kidney disease. Toxicol. Appl. Pharmacol., 238, 289-293.

6. Il'yasova, D. and Schwartz, G.G. (2005) Cadmium and renal cancer. Toxicol. Appl. Pharmacol., 207, 179-186.

7. Afkhami, A., Madrakian, T. and Siampour, H. (2006) Flame atomic absorption spectrometric determination of trace quantities of cadmium in water samples after cloud point extraction in Triton X-114 without added chelating agents. J. Hazard. Mater., 138, 269-272.

8. dos Santos, W.N., Costa, J.L., Araujo, R.G., de Jesus, D.S. and Costa, A.C. (2006) An on-line pre-concentration system for determination of cadmium in drinking water using FAAS. $J$. Hazard. Mater., 137, 1357-1361.

9. Silva, E.L., Roldan Pdos, S. and Giné, M.F. (2009) Simultaneous preconcentration of copper, zinc, cadmium, and nickel in water samples by cloud point extraction using 4-(2-pyridylazo)-resorcinol and their determination by inductively coupled plasma optic emission spectrometry. J. Hazard. Mater., 171, 1133-1138.

10. Robles, L.C. and Aller, A.J. (1995) Determination of cadmium in biological and environmental samples by slurry electrothermal atomic absorption spectrometry. Talanta, 42, 17311744.

11. da Costa, A.B., de Mattos, J.C.P., Müller, E.I., Paniz, J.N.G., Dressler, V.L. and de Moraes Flores, E.M. (2005) Use of paper capsules for cadmium determination in biological samples by solid sampling flame atomic absorption spectrometry. Spectrochim. Acta Part B, 60, 583-588.

12. Sanchez-Pedreño, C., García, M.S., Ortuño, J.A., Albero, M.I. and Expósito, R. (2002) Kinetic methods for the determination of cadmium(II) based on a flow-through bulk optode. Talanta, 56, 481-489.

13. Portugal, L.A., Ferreira, H.S., dos Santos, W.N.L. and Ferreira, S.L.C. (2007) Simultaneous pre-concentration procedure for the determination of cadmium and lead in drinking water employing sequential multi-element flame atomic absorption spectrometry. Microchem. J., 87, 77-80.

14. Lampugnani, L., Salvetti, C. and Tsalev, D.L. (2003) Hydride generation atomic absorption spectrometry with different flow systems and in-atomizer trapping for determination of cadmium in water and urine overview of existing data on cadmium vapour generation and evaluation of critical parameters. Talanta, 61, 683-698.

15. Talio, M.C., Luconi, M.O., Masi, A.N. and Fernández, L.P. 
(2009) Determination of cadmium at ultra-trace levels by CPE-molecular fluorescence combined methodology. J. Hazard. Mater., 170, 272-277.

16. Aleixo, P.C., Júnior, D.S., Tomazelli, A.C., Rufini, I.A., Berndt, H. and Krug, F.J. (2004) Cadmium and lead determination in foods by beam injection flame furnace atomic absorption spectrometry after ultrasound-assisted sample preparation. Anal. Chim. Acta, 512, 329-337.

17. Hernández-Caraballo, E.A., Burguera, M. and Burguera, J.L. (2004) Determination of cadmium in urine specimens by graphite furnace atomic absorption spectrometry using a fast atomization program. Talanta, 63, 419-424.

18. Coco, F.L., Monotti, P., Cozzi, F. and Adami, G. (2006) Determination of cadmium and lead in fruit juices by stripping chronopotentiometry and comparison of two sample pretreatment procedures. Food Control, 17, 966-970.

19. Hu, Q., Yang, G., Yin, J. and Yao, Y. (2002) Determination of trace lead, cadmium and mercury by on-line column enrichment followed by RP-HPLC as metal-tetra-(4-bromophenyl)porphyrin chelates. Talanta, 57, 751-756.

20. Skrzydlewska, E., Balcerzak, M. and Vanhaecke, F. (2003) Determination of chromium, cadmium and lead in food-packaging materials by axial inductively coupled plasma time-of- flight mass spectrometry. Anal. Chim. Acta, 479, 191-202.

21. Shams, E. and Torabi, R. (2006) Determination of nanomolar concentrations of cadmium by anodic-stripping voltammetry at a carbon paste electrode modified with zirconium phosphated amorphous silica. Sens. Actuators B, 117, 86-92.

22. Marino, G., Bergamini, M.F., Teixeira, M.F. and Cavalheiro, E.T. (2003) Evaluation of a carbon paste electrode modified with organofunctionalized amorphous silica in the cadmium determination in a differential pulse anodic stripping voltammetric procedure. Talanta, 59, 1021-1028.

23. Ly, S.Y., Yoo, H.S. and Chun, S.K. (2013) Detection of trace metal in distilled alcoholic drinks. Food Chem., 137, 168-171.

24. Ly, S.Y., Choi, D.W. and Kim, D.H. (2013) Diagnostic assay of glucose in diabetes patients' urine. Sens. Lett., 11, 19961999.

25. Ensafi, A.A., Khayamian, T., Benvidi, A. and Mirmomtaz, E. (2006) Simultaneous determination of copper, lead and cadmium by cathodic dsorptive stripping voltammetry using artificial neural network. Anal. Chim. Acta, 561, 225-232.

26. Ly, S.Y. and Choi, D.W. (2013) Implementation of a biocircuit implants for neurotransmitter release during neuro-stimulation. Curr. Neurovasc. Res., 10, 238-246. 